\title{
Implementation of Health Examination for Elector Recruitment Processes in the West Nusa Tenggara Province
}

\author{
Agus Supinganto ${ }^{1}$, Irwan Budiana ${ }^{2 *}$, P. Dewi Nur Sukma ${ }^{1}$, Ahmad Fudholi $^{3}$ \\ ${ }^{1}$ Department of Nursing, Yarsi High School of Health Sciences Mataram, West Nusa Tenggara Province, Indonesia; ${ }^{2}$ Department \\ of Nursing, Health Polytechnic Ministry of Health Kupang, Province East Nusa Tenggara, Indonesia; ${ }^{3}$ Solar Energy Research \\ Institute, Malaysian National University, Bangi, Malaysia
}

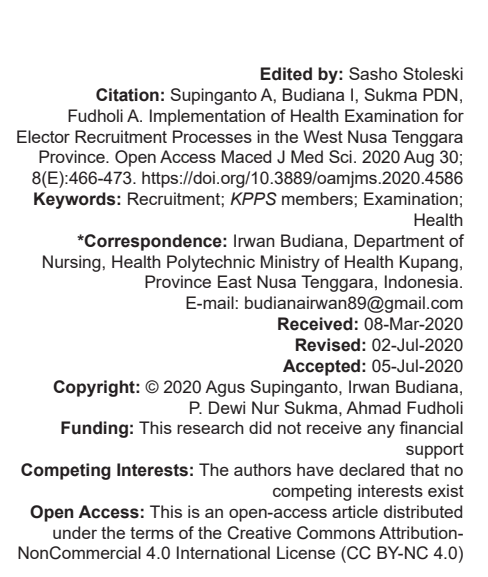

Abstract

BACKGROUND: The high number of cases of members of the Voting Officers Group (KPPS) who was sick and died in the simultaneous elections in 2019 is a record that the implementation of the simultaneous election implementation system has not been maximized, particularly relating to the recruitment and selection of election organizers.

AIM: This study aims to determine the implementation of the health inspection program for KPPS members in the recruitment process in West Nusa Tenggara Province in 2019

METHODS: The research design used in this study was non-experimental with a descriptive quantitative approach to describe a situation as it is. While the data analysis technique used is using descriptive statistics with percentages.

RESULTS: The results showed that the majority of respondents' health inspection planning was categorized as good $(50 \%)$, while the majority of respondents' health inspection implementation was categorized as poor $(60 \%)$ the majority of respondents' health inspection evaluations were good $(65 \%)$ and the health inspection for KPPS members in the recruitment process the majority of respondents are categorized as less (50\%).

CONCLUSION: In an effort to prevent morbidity or even fatalities at the election organizers, it is important to have a comprehensive plan related to the health inspection process for election organizer candidates including the road map for medical check-ups for election administrators.

\section{Introduction}

Elections or commonly abbreviated with the term election is one aspect of the democratic system that is very important to be held democratically. Decision of the Constitutional Court on January 23, 2014, has given many changes to the process of holding elections, in particular the change to a simultaneous general election held on April 17, 2019. The general election became the first general election held simultaneously in the history of Indonesian democracy. The election was conducted to elect directly the president and vice president, as well as members of the central People's Representative Council (DPR), Regional Representative Council $(D P D)$, provincial, and regency, or city Regional People's Representative Assembly (DPRDs) and carried out at 1 time and basically changing the pattern of organizing the elections aimed at realizing good governance in Indonesia, namely, effectiveness and efficiency in organizing elections. With the unification of the holding of elections there will be effectiveness and efficiency in terms of performance, time, and funding so that it is expected to be able to limit the organization of the previous elections. Simultaneous elections are expected to be able to minimize state funding, minimize political costs for election participants, as well as money politics involving voters, abuse of power or prevent politicization of the bureaucracy, and streamline government work schemes [1].

In the implementation of the change in the pattern of organizing the election, it actually creates many problems, especially in changing the workload of the election organizers, especially KPPS members. The stages of the simultaneous election organizers have gone through a process that takes a long time which aggravates the workload of KPPS members. In the 2019 KPPS handbook issued by General Election Commission (KPU) [2], it was stated that the KPPS's task in carrying out voting and counting at polling stations is one of them to realize voter sovereignty, serve voters using their voting rights, and provide access and services to disability voters in granting their voting rights. The stages of the election that must be passed by the members of the KPPS start from the inspection of the fittings at the polling station (TPS) along with documents consisting of five types of votes and ending with the vote counting process at the polling station at the polling station, which on average finishes 
at 01.00-03.00 PM. Not to mention if there are damaged ballots and ballots that are considered invalid, all of these stages are very burdening the work of the KPPS Members [3].

The holding of these simultaneous elections became one of the main causes of the increased workload of the election organizers, especially the workload of the members of the KPPS. The high workload is the main cause of many KPPS members who experience fatigue after working $24 \mathrm{~h}$ non-stop without rest so that not a few of the KPPS members are sick and died. Many of the KPPS members died due to fatigue due to the very high workload that KPPS members experienced in carrying out their duties. Based on KPU data of April 24, 2019, the number of sick KPPS members was 883 while the number of KPPS members who died numbered 144 people in various regions in 34 provinces. However, from the latest data in the KPU, which was recWorded as of May 4, 2019, at 16:00 WIB the total number of sick KPPS members was 3788 people and the number of KPPS members who died as many as 440 people [4].

According to the Ministry of Health investigations in four different provinces (Jakarta, West Java, Riau Islands, and Southeast Sulawesi), the election organizer who died from DKI Jakarta was caused by myocardial infarct, heart failure, hepatic coma, stroke, respiratory failure, and meningitis. Whereas in West Java caused by heart failure, stroke, respiratory failure, sepsis, and asthma, while in the Riau Islands the death of election management officers caused by heart failure, accidents, and in Southeast Sulawesi caused by accidents.

The high number of cases of KPPS members who died in simultaneous elections for the first time is a general illustration of the quality of the election administration system, especially relating to the recruitment process of election organizers (KPPS members). Health conditions that are not prepared properly will be exacerbated by the very heavy workload of officers in holding simultaneous elections. According to the preliminary studies conducted by researchers before almost all members of the KPPS interviewed researchers in several regions of West Nusa Tenggara Province (NTB) said that this election was the most tiring and most complicated, whose activities started from the preparation of TPS development, the voting process until the calculation sound. Based on the observation of the researchers directly, the vote count process that takes a long time is the calculation for DPRD members. All of the activities were only carried out by seven KPPS members, and not all of the KPPS members were in good health and not all were young. Prime health is the main capital of KPPS members; health has a direct influence on the quality and strength of work. According to research Piri, 2012 [5], health factors give a significant influence on the safety of workers, the more increasing the health value of workers, the lower the risk of workers' safety threats.

The high case of KPPS members who are sick and died in carrying out their duties is economical for researchers to basically be avoided or minimized if only the process of recruitment, selection, and placement of election administrators prioritizes the health of candidates before being assigned or carrying out tasks, both physical (biological), health psychology, and social health including spiritual health. In KPU RI regulation number 36 (years 2018) concerning amendment of KPU, regulation number 3 (years 2018) concerning the formation, and working procedures of the sub-district election committee ( $P K K)$, the voting committee (PPS), and the polling group (KPPS) in organizing general election article 36 regarding the requirements to become PKK, PPS, and KPPS states that candidates must be able or physically healthy, spiritually, and free of narcotics abuse [6].

The regulation does not mention efforts to prevent the deterioration of the health of candidates with high risk health, for example, through a certificate of passing a complete health examination from health services so that candidates for election management meet plenary health requirements. Even so, several regency and city KPUs [2] require a certificate of physical and spiritual ability from the local health center or hospital to be one of the documents that must be completed by the recruitment participants of the members of KPPS but sparing researchers who know about very precise management of health checks to obtain a certificate of physical and mental health, especially in rural areas are still far from what is expected when compared to the workload of KPPS members.

As a central and strategic factor in the successful implementation of national standard health selection elections for KPPS members it should be a priority, especially in the recruitment, selection, and forging process. This is the beginning of the creation and formation of a reliable and qualified and competent election organizer. If the election organizer's recruitment system prioritizes the safety of the organizer, the selection process will be carried out in accordance with health standards or predetermined methods to recruit candidates for the election organizer who are not only competent and able to carry out their duties properly and correctly but also the election organizer is able to withstand even difficult terrain or conditions such as excessive workloads.

Based on the background description above, the researcher is very interested in examining more closely the implementation of the health examination of KPPS members in the recruitment process of simultaneous election administrators in 2019. The purpose of this study is to find out the implementation of the inspection program or health test for members of the KPPS in the process recruitment in West Nusa Tenggara Province. 


\section{Methods}

This research is a non-experimental research with quantitative descriptive design and survey approach. This approach was used to describe the actual situation of the implementation of the health inspection program for KPPS members in the simultaneous election recruitment process in 2019. The population and sample in this study were the KPPS at the 2019 general election in West Nusa Tenggara Province with sample criteria that are, being a member or chair of KPPS, able to read well and be willing to be a research respondent. While the sampling technique uses a probability sampling approach with a simple random sampling approach, where members of the population have the same opportunity to be selected as research samples [7].

The instrument used in this study was a questionnaire or also called a questionnaire which was compiled to determine the implementation of health checks in the recruitment process of election administrators, especially the recruitment of members of the KPPS. While the analysis of the data used includes univariate analysis to determine the health examination in the recruitment process of the simultaneous election administrators in 2019 (recruitment of KPPS members), then after the data are collected it will be biblized and presented. Meanwhile, to find out the criteria of respondents in scoring data for each factor, categorization is done, namely, good category (76-100\%), adequate category (56-75\%), and less category $(<56 \%)$.

\section{Results and Discussion}

\section{Characteristics of respondents}

Characteristics of respondents who participated in this study include: Age, sex, last education, marital status, employment, income, health complaints, or illness before serving as KPPS, ownership of health insurance (BPJS Health), and previous medical history.

Characteristics of research respondents' by age are shown in Table 1.

Table 1: Distribution of respondents by age level

\begin{tabular}{lll}
\hline Employment status & $\mathrm{F}$ & $\%$ \\
\hline$<20$ years & 1 & 5 \\
$20-40$ years & 14 & 70 \\
$>40$ years & 5 & 25 \\
Total & 20 & 100 \\
\hline Source: Primary Data 2019 & &
\end{tabular}

Based on Table 1 shows that the majority of the age of the respondents were at the age of 20-40 years which amount to 14 people $(70 \%)$. The majority of the age of the respondents are in the condition of optimal intellectual ability to carry out an activity. According to the research results of the UGM election working group coordinating members of the KPPS who edited were in the age range of $50-70$ years and $39 \%$ edited after arriving or after receiving treatment in the hospital. Meanwhile, according to the results of the study, Atiqoh, 2014 [8], shows that there was a relationship between age and work fatigue in the Convection Workers in the Tailoring Division at CV. Various Gunungpati Garment Semarang. Meanwhile, according to research, Harmiyati, 2016 [9], shows that there is no significant relationship between age and performance with the results of statistical tests showing that $p=0.624(>0.05)$.

Characteristics of research respondents' by sex are shown in Table 2.

Table 2: Distribution of respondents by sex

\begin{tabular}{lll}
\hline Sex & F & $\%$ \\
\hline Male & 17 & 85 \\
Female & 3 & 15 \\
Total & 20 & 100 \\
\hline Source: Primary Data 2019. & &
\end{tabular}

Based on Table 2 shows that the majority of respondents in this study were male, namely 17 people (85\%).According to research, Sapariah, 2015[10], shows that gender influences performance. This was obtained after doing the Chi-square test with an independent test between two factors obtained calculated value is greater than $\chi 2$ images that are $21.65>3.84$. Scheidegger, Amy L. Ridley Meyers, and Karen Friedlen, in a study Albrecht and Jones [11] suggested that: "Males were more satisfied and confident and had fewer difficulties than females the process of adjustment appears to be gradual." This means that men are more easily satisfied and confident and have fewer difficulties than women. Whereas Nasaruddin Umar in Janah 2017 [12], gender is more than just the differentiation of men and women in terms of social and cultural construction and the results of research [9] show that there is no relationship between sex and one's performance.

In general, physical and male workers are much stronger to survive in work situations that have heavier workloads. However, it is not uncommon in some areas for male incentives to be different from women, except in work situations that do not require higher energy, such as in offices, schools, or other public services such as in government offices.

Characteristics of research respondents' based on education level are shown in Table 3.

Table 3: Distribution of respondents base on education level

\begin{tabular}{lll}
\hline Education level & $\mathrm{F}$ & $\%$ \\
\hline No school & 0 & 0 \\
Primary school & 0 & 0 \\
Junior high school & 0 & 0 \\
Senior high school & 6 & 30 \\
University & 14 & 70 \\
Total & 20 & 100 \\
\hline Source: Primary Data 2019. & &
\end{tabular}

Based on Table 3, the distribution of respondents based on their latest level of education shows that most of the respondents had a final education at a tertiary institution (PT) of 14 people (70\%). This can be caused by the lack of community participation with 
final education under a PT who follows the recruitment process to become KPPS.

According to the results of the study, Wirawan, 2016 [13], shows that there is a positive influence from the level of education on employee performance. While the research, Amperaningsih, 2013 [14], states that there is no relationship between the education of respondents with the implementation of Public Health with the results of statistical tests that $p=0.436$ is obtained (> alpha 0.05). Likewise the research conducted, Harmiyati, 2016, [9] showed that there was no significant relationship between education and the performance of nurses in public health centers in the city of Palembang ( $p=0.627$ ). In addition, according to Esteslita 2011 [15], it is stated that education does not correlate with paramedic performance with $p=0.4110$. The formal education level indicates the intellectual level or level of knowledge of a person. It can be understood that with higher education a person has more opportunities to get information and he is better trained to manage, understand, evaluate, remember, and then become the knowledge he has.

The educational background of a person will affect their perceptions, perspectives, and attitudes in seeing work or the problems they face, as well as job satisfaction so it can be assumed that the higher the level of education a person takes, the more different perceptions will be in addressing the problem. Educational background is one of the factors that support whether or not the quality of one's work. In general, people who have higher education will have broader insight, especially appreciation of the importance of productivity. The high awareness of the importance of productivity can encourage employees to take productive actions. Higher education will also encourage someone to be more creative.

Characteristics of research respondents' base on marital status are shown in Table 4.

Table 4: Distribution of respondents base on marital status

\begin{tabular}{lll}
\hline Marital status & F & $\%$ \\
\hline Married & 15 & 75 \\
Single & 5 & 25 \\
Widow & 0 & 0 \\
Widower & 0 & 0 \\
Total & 20 & 100 \\
\hline Source: Primary Data 2019. & &
\end{tabular}

Based on Table 4, the distribution of respondents based on marital status that the majority of respondents were married with the number of respondents, i.e., 15 people or $75 \%$. The lack of respondents is married due to several reasons, one of which is the respondent does not feel ready or feels financially or economically independent. According to the results of the study, Harmiyati, 2016 [9], showed that there was no significant relationship between marital status with the performance of the nurse in public health centers with the results of statistical tests showed that the $p=0.964(>0.05)$.

Whereas according to Geraldi 2016 [16], the correlation test results show that marital status with employee motivation has a strong relationship of 0.617 . The results of the coefficient of determination of marital status test contributed to employee motivation by $38.06 \%$, the remaining $61.94 \%$ is influenced by other variables that are not measured so that the hypothesis test results of the calculated $t$ value is greater than the image $t(7.76>1.660)$, meaning marital status has a positive effect on employee motivation so that it can be said that marriage will make KPPS members more responsible.

Characteristics of research respondents' base on type of work are shown in Table 5.

Table 5: Distribution of respondents base on type of work

\begin{tabular}{lll}
\hline Profession & $\mathrm{F}$ & $\%$ \\
\hline Government employees & 4 & 20 \\
Private & 7 & 35 \\
Entrepreneur & 2 & 10 \\
The farmer & 0 & 0 \\
Other & 7 & 35 \\
Total & 20 & 100 \\
\hline Source: Primary Data 2019. & &
\end{tabular}

Based on Table 5, the distribution of respondents by occupation shows that most respondents work in the private sector with various other professions, namely, seven people (35\%). According to the study, Harmiyati, 2016, [9] showed that there is a significant relationship between the type of work and the performance of nurses in the Public Health Center in Palembang City Health Center with statistical test results showing that $p=0.012$. While according to Amperaningsih 2013 [14], there is a significant relationship between the length of work of nurses with the implementation of the Public Health Program with the statistical test results obtained $p=$ 0.027 (< alpha 0.05).

Basically, the type of work can be linked to different work experience. This supports the previous theory which states that one of the factors that can affect individual performance is experience, the more individual experience, the higher the performance.

The length of work of a person also determines one's performance, because the longer and more experience a person has, the more skills will be known and will provide confidence, have an attitude when facing work or problems, so the quality of performance will be better.

Meanwhile, according to Ratnia, 2019 [1], there is no relationship between performance and employment status or the same and there is no difference with an absolute $\mathrm{t}=0.8$ (far below the value of 2 ), and a significance value (sig) of $0.75(>0.05)$ is said to be significant if the value of sig $<0.05$ and according to Atiqoh 2014 [8], there is a relationship between work tenure and work fatigue for workers.

Characteristics of research respondents' base on income are shown in Table 6.

Based on Table 6, the distribution of respondents based on the income of the majority of 
respondents earn $<$ Rp. 1,000,000 of which eight people or $42 \%$. According to research of the study, Riyadi, 2011 [17], shows that financial compensation has no effect on work motivation or employee performance, this can occur because of the respondents chosen by managers who are in the middle level, in these conditions the expectations of each respondent are not merely the intended financial compensation, but non-financial compensation can be considered and determine the quality of work of employees. If the employee's perception of the reward he receives is inadequate, then it is likely that the employee will try to obtain a greater reward or reduce the intensity of his business.

Table 6: Distribution of respondents base on income

\begin{tabular}{lll}
\hline Income & $\mathrm{F}$ & $\%$ \\
\hline$<1$ Million & 8 & 42 \\
$1-3$ Million & 5 & 26 \\
$>3$ Million & 6 & 31 \\
Total & 20 & 100 \\
\hline Source: Primary Data 2019.
\end{tabular}

Characteristics of research respondents' base complaints before duty are shown in Table 7.

Table 7: Distribution of respondents base on complaints before duty

\begin{tabular}{lll}
\hline Complaints before duty & F & $\%$ \\
\hline There are complaints & 0 & 0 \\
There are not complaint & 20 & 100 \\
Total & 20 & 100 \\
\hline Source: Primary Data 2019. & &
\end{tabular}

Based on Table 7, the distribution of respondents is based on the presence or absence of KPPS members' pre-test or before serving duties, amounting to 20 people (100\%). The quality of the health of prospective KPPS members is very important to be identified to ensure the election $K P U$ gets KPPS members who are truly healthy and ready to work in any situation to succeed in holding simultaneous elections in 2019. This is very important because when the KPU accepts someone becomes KPPS members then the KPU should be responsible for the health of the KPPS members while doing work (Law No. 1/1970 which contains companies obliged to provide protection for the safety and health of employees in their company).

Characteristics of research respondents' base on BPJS health membership are shown in Table 8.

Table 8: Distribution of respondents base on BPJS Health Membership

\begin{tabular}{lll}
\hline BPJS health membership & F & $\%$ \\
\hline Participant & 14 & 70 \\
An participant & 6 & 30 \\
Total & 20 & 100 \\
\hline Source: Primary Data 2019. & &
\end{tabular}

Based on Table 8, the distribution of respondents based on BPJS Health membership, the majority became BPJS Health members, amounting to 14 people $(70 \%)$. Difficult access in health services for the community which is generally influenced by financial factors. People who suffer from serious illnesses cannot be cured because of the lack of medical expenses so that in the end they are slow to treat or not treated at all so that eventually the disease gets worse and even results in death [18].

Characteristics of research respondents' base on ownership of a history of disease are shown in Table 9.

Table 9: Distribution of respondents base on ownership of a history of disease

\begin{tabular}{lll}
\hline History of disease & F & $\%$ \\
\hline There are history of disease & 5 & 25 \\
There are not history of disease & 15 & 75 \\
Total & 20 & 100 \\
\hline Source: Primary Data 2019. & &
\end{tabular}

Based on Table 9, the distribution of respondents based on ownership of the majority of disease history does not have a history of 15 people or $75 \%$. Information from prospective KPPS members about personal history or family history is very important to be identified to anticipate or prevent sufferers more vulnerable or more sensitive to exposure experienced [19].

\section{Research core data}

The research core data include several aspects, namely, aspects of planning, planning implementation, evaluation process, and implementation of health inspection activities or health tests in the recruitment process of prospective election KPPS members simultaneously in 2019.

Planning an examination or health test for prospective KPPS members is shown in Table 10.

Table 10: Distribution of respondents based on inspection plans or health tests for prospective KPPS members

\begin{tabular}{lll}
\hline Plans & F & $\%$ \\
\hline Good & 10 & 50 \\
Enough & 8 & 40 \\
Lacking & 2 & 10 \\
Total & 20 & 100 \\
\hline Source: Primary Data 2019. & &
\end{tabular}

Based on Table 10, the distribution of respondents based on the planning of health examination activities for prospective members of the KPPS at the same time in 2019, the majority were in the good category $(50 \%)$. HR planning is basically a selection of policies and strategies regarding labor and analysis of future workforce need both in quantity and quality so as to be able to anticipate both shortages and excess human resources for the achievement of the organization effectively and efficiently [20].

According to the research results in the planning process, $75 \%$ of respondents revealed that the $K P U$ issued a Decree, an assignment letter, or the like about the prospective KPPS member carrying out checks or medical tests in the recruitment process of prospective KPPS members, $55 \%$ revealed the KPU did not organize KPPS members in conduct inspection activities or health tests in the recruitment process of KPPS members. This means that prospective KPPS members conduct health checks independently on their own initiative. About $65 \%$ said that the KPU did the scheduling and socialized the schedule for conducting 
medical examinations or examinations in the recruitment process of prospective KPPS members. About $55 \%$ revealed that the KPU brought in or cooperated with health services for health inspection activities in the recruitment process of prospective KPPS members and $70 \%$ said passing the examination or medical test was the main requirement for graduation to become a KPPS member.

The planning of health examination for prospective KPPSmembers aims to find a comprehensive picture of the health condition of prospective KPPS candidates. Not only the current condition but also included with a history of late illness and family disease. Referring to the opinion of in Adawiyah, 2013 [20], it can be concluded that one of the important stages in the HR planning process is Gathering, Analyzing, and Forecasting Supply and Demand Data. At this stage, a number of activities are carried out to collect, investigate, analyze, and predict data need to determine supply and demand. Data sources can come from internal and external environments, which are studied or explored based on past experience, observations in the present, and predictions of future needs.

Examination health test for prospective KPPS members is shown in Table 11.

Table 11: Distribution of respondents based on the examination or health test of prospective KPPS members

\begin{tabular}{lll}
\hline Implementation & F & $\%$ \\
\hline Good & 1 & 5 \\
Enough & 7 & 35 \\
Lacking & 12 & 60 \\
Total & 20 & 100 \\
\hline Source: Primary Data 2019. & &
\end{tabular}

Based on Table 11, the distribution of respondents based on the implementation of health checks for the majority of prospective KPPS members is categorized as less $60 \%$. In the process of carrying out the health examination for prospective KPPS members, there are a number of important points to be carried out as an effort to prevent the deteriorating condition of KPPS members while on duty other checkup.

According to the results of this study, $75 \%$ said that health workers did not do a complete physical examination that starts from the tip of the hair to the tip of the head (Head to toe). Physical examination carried out is merely observing without applying the PPA approach (Percussion or by tapping, Palpation or feeling, and Auscultation or listening) in a comprehensive manner. An incomplete examination will certainly cause lack of information about a person's health and will depend on the determination of further diagnoses and management, 55\%. Respondents said that health workers did not check vital signs (exhalation, pulse, blood pressure and temperature), meaning that prospective KPPS members only received a letter of confidentiality without checking vital signs (TTV), while respondents who received TTV examinations claimed only get a blood pressure check without other checks.
While health workers who did not carry out radiological examinations using $X$-rays or radioactive rays reached $95 \%$. This shows that the medical examination obtained by KPPS members prior to duty is still far from the standard that has been set, so preventive action is difficult.

The results also showed that $75 \%$ of respondents said that health workers did not carry out laboratory examinations such as hematological (blood) tests of urine and $85 \%$ of respondents said that health workers did not carry out checks on lung function, cholesterol, uric acid, and blood sugar. The lack of this type of examination is closely related to the patient's own request and the type of examination that the patient needs. Likewise from the $K P U$, it is not that does not require the examinations, so it is not due to non-compliance by health workers.

Evaluation of examination or health test for prospective KPPS members is shown in Table 12.

Table 12: Distribution of respondents based on evaluation of examinations or health tests of prospective KPPS members

\begin{tabular}{lll}
\hline Evaluation & $\mathrm{F}$ & $\%$ \\
\hline Good & 10 & 50 \\
Enough & 3 & 15 \\
Lacking & 7 & 36 \\
Total & 20 & 100 \\
\hline Source: Primary Data 2019. & &
\end{tabular}

Based on Table 12, the distribution of respondents based on the evaluation of health checks on the recruitment of prospective members of the KPPS is categorized as good (50\%). In the process of evaluating the health examination process for prospective KPPS members, there are several things that must be done such as analyzing the results of examinations, reporting the results, and so on. According to the research results of health workers who provide health education to the results of the health examination prospective KPPS members only $55 \%$, while health workers who provide written reports on the results of examinations or health tests to prospective KPPS members only $55 \%$. Meanwhile, according to $60 \%$ of KPU respondents did not announce in writing or stipulate the passing of a health examination for prospective KPPS members. The KPU should carry out an evaluation of the examination or health test activities as the main requirement for the recruitment of KPPS members, but only $55 \%$ of respondents said that the KPU conducted the evaluation. Meanwhile, according to $50 \%$ of KPU respondents did not report health inspection activities as the main requirements for the recruitment of KPPS members. According to in Rengganis 2013 [21], at any institution, before hiring employees generally perform various tests, including medical tests. Even when applying, prospective employees must attach a health certificate from.

Execution of prospective KPPS member checks or medical tests is shown in Table 13. 
Table 13: Distribution of respondents based on the conduct of examinations or health tests (MCU) of prospective KPPS members

\begin{tabular}{lll}
\hline Execution of MCU & $\mathrm{F}$ & $\%$ \\
\hline Good & 3 & 5 \\
Enough & 7 & 45 \\
Lacking & 10 & 50 \\
Total & 20 & 100 \\
\hline Source: Primary Data 2019 & &
\end{tabular}

Based on Table 13, the distribution of respondents based on the implementation of a medical check-up (Medical Check Up) that the majority of prospective KPPS members are categorized as less $50 \%$. The main purpose of the pre-employment medical check-up in addition to being useful for the institution is also beneficial for prospective staff. For institutions, it is clear that there will be healthy employees and, of course, physically able to carry out tasks or jobs that will be charged. In addition, the company or institution avoids the spread of the disease, if the candidate accepted as the employee turns out to suffer from an infectious disease. As for the prospective staff concerned can find out their health status, and make efforts to overcome their health problems.

\section{Conclusion}

Based on the results of the study, it can be concluded as follows:

1. Planning a health examination the majority of respondents was in the good category $(50.00 \%)$.

2. The majority of respondents conducted health checks under the category of lack $(60.00 \%)$.

3. The evaluation of the health inspection activities of the majority of respondents was in the good category $(65.00 \%)$.

4. The implementation of medical check-up (Medical Check Up) for KPPS members in the process of recruiting the majority of respondents categorized as less $50.00 \%$.

\section{Recommendation}

follows:

Recommendations that can be given are as

1. Making a comprehensive plan related to the health examination process for election organizer candidates (KPPS), it is important to do to improve the quantity and quality of election organizers.

2. Making a standard road map for health checks (Medical Check Up) for election administrators.

3. Strengthening cross-sectorial cooperation, especially with health services to carry out health screening activities.

\section{References}

1. Solihah R. Peluang dan tantangan pemilu serentak 2019 dalam perspektif politik. JIIP. 2018;3(1):73-88. https://doi.org/10.14710/ jiip.v3i1.3234

2. KPU. Pengumuman-daftar-calon-anggota-KPPS. Jepara: KPU; 2019. p. 1-3. Available from: https://www.KPUjepara.go.id/ wp-content/uploads/2019/02/104.Pengumuman-Daftar-Calonanggota-KPPS.pdf. [Last accessed on 2020 Jan 10]

3. Budi, Sidiq, and Dewi Sendhikasari. Jaminan Pemerintah Terhadap Anggota KPPS Dalam Pemilu Serentak 2019. Info Singkat XI; 2019. p. 25. Available from: https://www.berkas. dpr.go.id/puslit/files/info_singkat/InfoSingkat-XI-9-I-P3DIMei-2019-2081. pdf. https://doi.org/10.37295/wp.v13i01.10. [Last accessed on 2020 Jan 10].

4. Purwanto EA. Kajian Lintas Disiplin Atas Meninggal Dan Sakitnya Petugas Pemilu 2019. Kerala: Riset Kajian Lintas Disiplin UGM; 2019. p. 4-6. Available from: https://www.KPU.go.id/ koleksigambar/20190625_Prescon_Kajian_Lintas_Disiplin_ atas Meninggal dan Sakitnya Petugas pemilu 2019.pdf. https://doi.org/10.24198/metahumaniora.v9i1.22870. [Last accessed on 2020 Jan 15].

5. Piri S, Sompie BF, Timboeleng JA. Pengaruh kesehatan, pelatihan dan penggunaan alat pelindung diri terhadap kecelakaan kerja pada pekerja konstruksi di Kota Tomohon. J IImiah Media Eng. 2012;2(4):219-31. https://doi.org/10.24198/ jsk.v3i4.18497

6. KPU. Peraturan Komisi Pemilihan Umum (KPU) Nomor 36 Tahun 2018 Tentang Perubahan Peratuan KPU Nomor 3 Tahun 2018 Tentang Pembentukan Dan Tata Kerja Panitia Pemilihan Kecamatan (PKK), Panitia Pemungutan Suara (PPS), Dan Kelompok Penyelenggara Pemungutan Suara; 2018. p. 1-17.

7. Nurdin N, Hamdhana D, Iqbal M. Aplikasi quick count pilkada dengan menggunakan metode sample random sampling berbasis android. TECHSI. 2018;10(1):141-54. https://doi. org/10.29103/techsi.v11i1.1401

8. Atiqoh J, Wahyuni I, Lestantyo D. Faktor-faktor yang berhubungan dengan kelelahan kerja pada pekerja konveksi bagian penjahitan di CV. Aneka garment Gunungpati Semarang. J Kesehatan Masyarakat. 2014;2(2):119-26. https:// doi.org/10.37012/jik.v11i1.70

9. Harmiyati L. Pengaruh karakteristik dan kapabilitas individu serta karakteristik organisasi terhadap persepsi kinerja perawat perkesmas ditetapkan sebagai upaya pengembangan di terhadap keluarga rawan kes. J Kedokteran Kesehatan. 2016;3(1):341-9. https://doi.org/10.31602/alsh.v4i2.1851

10. Sapariah M. Analisis Pengaruh Jenis Kelamin Terhadap Kinerja Karyawan Bagian Perawatan Pada PT. Mulia Bhakti Kahuripan, Doctoral Dissertation. Indonesia: UM Pontianak; 2015.

11. Albrecht AC, Jones DG. Web-based research tools and techniques. In: Walz GR, Bleuer JC, Yep RK, editors. Compelling Counseling Interventions: VISTAS. Alexandria, VA: American Counseling Association; 2009. p. 337-47.

12. Janah $\mathrm{N}$. Telaah buku argumentasi kesetaraan gender perspektif al-Qur'an Karya Nasaruddin umar. Sawwa. 2017;12(2):167-86. https://doi.org/10.21580/sa.v12i2.1707

13. Wirawan KE. Pengaruh tingkat pendidikan dan pengalaman kerja terhadap kinerja karyawan. Bisma. 2019;4(1):1-9. https:// doi.org/10.26740/bisma.v4n1.p15-25

14. Amperaningsih YD. Kinerja perawat dalam pelaksanaan perkesmas. J Kesehatan Politkenik Tanjung Karang. 2013;4(1):204-13.

15. Esteslita. Faktor Faktor Yang Berhubungan Dengan Kinerja Paramedis Di RSUD Ahmad Yani Metro; 2011. 
16. Geraldi M. Pengaruh Status Pernikahan Terhadap Motivasi Kerja Karyawan di Yogya Center Bandung. Indonesia: Universitas Widyatma. 2016. Available from: https://www.repository. widyatama.ac.id/xmlui/bitstream/handle/123456789/4633/ Cover.pdf?sequence=1. [Last accessed on 2020 Jan 15].

17. Riyadi S. Pengaruh kompensasi finansial, gaya kepemimpinan, dan motivasi kerja terhadap kinerja karyawan pada perusahaan manufaktur di Jawa Timur. J Manajemen Kewirausahaan. 2011;13(1):40-5. https://doi.org/10.9744/jmk.13.1.40-45

18. Putri NE. Efektivitas penerapan jaminan kesehatan nasional melalui BPJS dalam pelayanan kesehatan masyarakat miskin di Kota Padang. Tingkap. 2014;10(2):175-89. https://doi. org/10.24167/shk.v3i1.694
19. Andhika P. Perbandingan Tingkat Kinerja Keselamatan dan Kesehatan Kerja Sebelum dan Sesudah Penerapan Ohsas 18001 di PT. Phapros, Tbk. Indonesia: Diponegoro University Institutional Repiository; 2016. Available from: http://www. eprints.undip.ac.id/47990. https://doi.org/10.37403/financial. v5i2.108. [Last accessed on 2020 Jan 10].

20. Adawiyah W, Sukmawati A. Analisis beban kerja sumber daya manusia dalam aktivitas produksi komoditi sayuran selada (Studi Kasus: CV Spirit Wira Utama). J Manajemen dan Organ. 2013;4(2):128-43. https://doi.org/10.29244/jmo.v4i2.12619

21. Rengganis SA. Analisis Implementasi Pemeriksaan Kesehatan pada Karyawan di Bagian Produksi PT. Frisian Flag Indonesia Tahun. 2012: 2015; 2013 